\title{
Peningkatan Keterampilan Berbicara dengan Bercerita Menggunakan Komik Elektronik Tematik
}

\author{
Suci Aprilyati Ruiyat ${ }^{1}$, Yufiarti ${ }^{2}$, Karnadi $^{3}$ \\ Pendidikan Anak Usia Dini, Universitas Negeri Jakarta
}

\begin{abstract}
Abstrak
Penelitian ini bertujuan untuk meningkatkan keterampilan berbicara anak kelompok B TK Setia Budhi Rangkasbitung dengan bercerita menggunakan komik elektronik tematik. Penelitian dilakukan pada bulan Maret sampai Juli 2019, hasil observasi pemasalahan pada anak kelompok B TK Setia Budhi masih kurang dalam berkomunikasi, baik dalam pengucapan kata/huruf, sedikitnya pembedaharaan kosakata anak, serta kurangnya kemampuan anak mengucapkan suatu kalimat dengan lancar, mengakibatkan anak belum dapat mengungkapkan gagasannya secara utuh. Metode penelitian menggunakan Penelitian Tindakan mengacu pada model Kemmis dan Mc. Taggart. Menerapkan dua siklus dengan 10 pertemuan. Menggunakan instrumen data wawancara, observasi dan dokumentasi selama penelitian untuk reduksi data, display data dan verifikasi data. Hasil penelitian didapatkan bahwa penggunaan komik elektronik tematik membantu menjawab permasalahan keterampilan berbicara anak di TK Setia Budhi.
\end{abstract}

Kata Kunci: Keterampilan berbicara; bercerita; komik elektronik

\begin{abstract}
This study aims to improve group B in speaking skills at TK Setia Budhi Rangkasbitung by storytelling using thematic electronic comics. The study was conducted in March to July 2019, based on observations of problems in group B at Setia Budhi Kindergarten, they were still lack in communication, both in pronunciation of words / letters and lack of children's ability to pronounce a sentence fluently. Those were caused by dissection of children's vocabulary and children could not express their ideas as a whole. The research method used Action Research that refers to the Kemmis and Mc Class Action Research model. Taggart. Implemented two cycles with 10 meetings. The data analysis technique used in this study was qualitative by analyzing data from interviews, observing documentation during the study for data reduction, data display and data verification. The use of thematic electronic comics helped answer the problem of speaking skills at Setia Budhi Kindergarten. The sample of this study were 13 childrens, five boys and eight girls. From the research conducted there was a significant increase in the speaking skills of children aged 5-6 years. There was an increase from pre-intervention $33.33 \%$ to $60.47 \%$ and then in second cycle reached $80.55 \%$, it can be stated that the use of thematic electronic comics can provided solutions to improve the speaking skills of children aged 5-6 years at Setia Budhi Rangkasbitung Kindergarten.
\end{abstract}

Keywords: Speaking skills; Storytelling; electronic comics

Copyright (c) 2019 Suci Aprilyati Ruiyat, Yufiarti, Karnadi

$\triangle$ Corresponding author:

Address : Kabupaten Lebak Provinsi Banten

Email : suciaprilyati_paud15s2@mahasiswa.unj.ac.id

ISSN 2356-1327 (Media Cetak)

ISSN 2549-8959 (Media Online) 


\section{PENDAHULUAN}

Berbicara merupakan cara berkomunikasi yang dilakukan untuk menyampaikan keinginan atau perasaan yang sedang dirasakan. Keterampilan berbicara sangat dibutuhkan oleh anak, dengan berbicara anak sedang mengembangkan perkembangan bahasanya, melatih anak dalam pembendaharaan kosakata sehingga lebih luas dalam mengenal bahasa dan mempersiapkan anak untuk melanjutkan ke tahap menulis dan membaca diakhiri dengan menyimak.

Handoko mengatakan gangguan berbicara pada anak disebabkan karena beberapa faktor, diantaranya faktor internal maupun eksternal pada diri anak. Anak dapat terstimulus dengan baik apabila peran orang disekitar maupun gen anak terangsang dengan baik. Penyebab tersebut tidak dapat dipecahkan satu sama lain karena pemberian tindakan berbeda sesuai dengan penyebabnya (Handoko, 2018).

Keterampilan berbicara merupakan salah satu perkembangan bahasa yang dikembangkan pada anak usia dini, sebagai alat komunikasi dan sarana untuk mengungkapkan yang dirasa. Sudah seharusnya anak dapat terstimulasi agar dapat mengungkapkannya segala sesuatu yang diinginkan, dan mencari tahu apa yang ingin diketahuinya. Pada usia 3-5 tahun Berbicara merupakan bentuk komunikasi secara lisan yang berfungsi untuk menyampaikan maksud dengan lancar, menggunakan kata-kata, dan menggunakan kalimat dengan jelas. (Aprinawati, 2017) Kosa kata yang dimilikinya pula harus bervariatif menjawab pertanyaan yang lebih kompleks, menyebutkan kelompok gambar yang memiliki bunyi yang sama, berkomunikasi secara lisan, memiliki perbendaharaan kata, serta mengenal simbol-simbol untuk persiapan membaca, menulis dan berhitung menyusun kalimat sederhana dalam struktur lengkap (pokok kalimat-predikat dan keterangan), memiliki lebih banyak katakata untuk mengekpresikan ide pada orang lain, melanjutkan sebagian cerita/dongeng yang telah diperdengarkan (Pendidikan, Kebudayaan, \& Indonesia, 2014)

Menurut Zuhriyah Keberhasilan dilihat dari kemampuan berbicara peserta didik. Ada banyak alasan mengapa mereka mengalami kesulitan dalam berbicara, seperti kurangnya ide untuk diceritakan, kurangnya kosa kata untuk mengekspresikan ide, kurangnya kesempatan untuk berbicara, dan kurangnya metode pengajaran yang menarik yang dapat memotivasi mereka untuk berbicara (Zuhriyah, 2017).

Tambunan, (2016) Kemampuan berbicara memang dapat dimiliki oleh semua manusia normal. Akan tetapi, keterampilan berbicara tidak dapat dimiliki oleh setiap manusia. Bukan berarti bahwa keterampilan berbicara tidak dapat dimiliki oleh semua orang. Setiap orang yang mau berlatih dengan sungguhsungguh dapat terampil berbicara. Untuk itulah pembelajaran berbicara diperlukan di sekolah. Harapannya agar siswa-siswa kita terampil berbicara

Terlihat pada perkembangan bahasa anak, anak masih malu dalam mengungkapkan emosi dengan berbicara. Kesulitan berbicara yang dialami ini merupakan tanpa bahwa anak harus distimulasi agar mudah dalam berkomunikasi dan menyampaikan pesan yang diinginkan. Kesempatan untuk berbicara juga faktor lain yang mengakibatkan kurangnya keterampilan berbicara anak.

Berbicara dapat menghasilkan beberapa kosakata yang lebih tinggi dan dapat menjadikannya kalimat yang memiliki makna tertentu. Masa anak mengucapkan sesuatu di lakukan secara terus menerus sehingga apa yang dilakukannya dapat menjadikan anak lebih 
mengetahui hal yang diinginkannya (Shiel, Cregan, Mcgough, \& Archer, 2012). Pengulangan yang dilakukan bertujuan agar anak mampu mengungkapkan sesuai dengan perasaan yang sedang dirasakannya. Pentingnya anak mengetahui kosakata awal diperuntukkan untuk kemampuan pada tahap berikutnya berupa membaca dan menulis. Anak yang dapat berbicara dengan baik akan lebih memudahkan pada pemahaman perkembangan bahasa dan akan mudah mengontrol emosi karena apa yang diinginkan dapat tersampaikan dengan baik.

Mabruri \& Aristya, (2017) menyatakan bahwa selama ini pengajaran keterampilan berbicara dan menyimak khususnya anak siswa belum sepenuhnya mempunyai kemampuan komunikatif, masih takut, malu, dan ragu ketika harus berbicara di depan umum dan menyampaikan gagasangagasannya. Penyebabnya dikarenakan guru tidak menggunakan media yang menarik sehingga anak tidak terpacu dalam kegiatan yang akan diberikan. Media yang digunakan guru merupakan salah satu pendukung terstimulusnya keterampilan berbicara.

Pratiwi, (2016) Berbicara merupakan suatu keterampilan, dan keterampilan tidak akan berkembang apabila tidak dilatih secara terus-menerus. Oleh karena itu, kepandaian berbicara tidak akan dikuasai dengan baik tanpa dilatih. Apabila selalu dilatih, keterampilan berbicara tentu akan semakin baik. Begitu pula sebaliknya, apabila malu, ragu, atau takut salah dalam berlatih berbicara, maka kepandaian atau keterampilan berbicara pun akan akan jauh dari penguasaan. Pembelajaran

Komik memang mudah didapatkan terbukti pada penelitian yang dilakukan Ramliyana, (2016) didapatkan hasil penelitian menunjukkan bahwa komik dapat digunakan secara efisien untuk meningkatkan penguasaan kosakata peserta BIPA. Oleh karena itu, penggunaan komik ke dalam pembelajaran memiliki dampak yang sama dengan penggunan metode permainan di dalam pembelajaran BIPA. Namun dalam pendidikan anak usia dini komik yang digunakan harulah menarik dan memiliki gambar yang variatif agar anak lebih termotivasi dalam mengucapkan kata sehingga dapat berbicara dengan baik dengan menggunakan komik elektronik tematik.

Menurut Rahadian pada bahasa Belanda komiek yang berarti "pelawak". Atau kalau dirunut dari bahasa Yunani kuno, istilah komik berasal dari kata “ komikos" yang merupakan kata bentukan dari "kosmos" yang berarti "bersuka ria" atau "bercanda" adi, dalam kaitan ini komik sering dikonotasikan dengan halhal yang lucu dan unsur kelucuan itu antara lain dilihat dari segi gambargambarnya yang tidak proporsional, tetapi mengenal. Rahmawati, (2017). Penggunaan komik sangat membantu melatih perkembangan berbicara anak.

Sedangkan menurut Behmer (dalam Smeda, 2014:3) Storytelling adalah sebuah proses di mana siswa mempersonalisasi apa yang mereka pelajari dan membangun makna dan pengetahuan mereka sendiri dari cerita yang mereka dengar dan katakan.(Metode et al., 2018)

Menurut Madyawati bercerita adalah suatu kegiatan yang dilakukan seseorang secara lisan kepada orang lain dengan alat tentang apa yang harus disampaikan dalam bentuk pesan, informasi atau hanya sebuah dongeng yang dikemas dalam bentuk cerita yang dapat didengarkan dengan rasa menyenangkan. (Pratiwi, 2016)

Kendala yang dialami oleh guru saat melakukan metode bercerita adalah kurang menariknya media yang dibuat oleh guru sebagaimana hasil obsesi Ayu Citra Dewi pada Taman Kanak-kanak kelompok B yang berada di kenagarian Maninjau dan Tanjung Sani Kecamatan Tanjung Raya, Kabupaten Agam bahwa Ketika guru 
bercerita dan berdiskusi dan saling tanya jawab dia hanya mendengarkan saja, ketika guru mengajaknya bicara dia diam saja. Anak tidak menunjukkan sikap yang antusias saat mengikuti pelajaran sepeti teman lainnya.(Dewi, Hapidin, \& Akbar, 2019) Bercerita yang akan dilakukan berupa bercerita menggunakan alat berupa komik elektronik tematik.

Komik elektronik disebut juga dengan komik digital, perkembangan teknologi khususnya dalam dunia digital memiliki dampak pada komik, dengan adanya komik elektronik yang diciptakan untuk penggemar komik. Menurut Ahmad (Syarah, Yetti, \& Fridani, 2018), komik elektronik dapat digolongkan berdasarkan aplikasi digital dikategorikan sebagai berikut : (a) Digital production, mengacu pada proses pembuatan komik dapat dilakuakn $100 \%$ pada layar elektronik tanpa manipulasi atau menggunakan digital sepenuhnya. (b) Digital Form, berdasarkan pada bentuk komik yang berbentuk komik elektronik yang memiliki kemampuan seperti borderless atau tidak seperti kertas yang dibatasi ukuran dan format, sehingga komik dapat mempunyai bentuk yang tidak terbatas, seperti memanjang ke samping atau ke bawah, bahkan berbentuk spiral. Komik elektronik juga memiliki factor waktu yang tidak terhitung, artinya jika komik bentuk cetak memiliki keterbatasan usia karena daya tahan kertas, maka komik elektronik yang berbentuk data elektronik dapat disimpan dalam bentuk digit atau byte, dan mudah ditransfer ke dalam berbagai macam media penyimpanan. Kelebihan lain dari komik elektronik ini adalah kemampuan multimedianya, dimana tampilan komik dapat dikombinasikan interaktifitas, suara dan sebagainya, sehingga mampu memberikan pengalaman membaca yang lengkap untuk para pemabacanya. (c) Digital delivery, berdasarkan kepada distribusi komik secara digital dalam bentuk tanpa kertas dan mobilitas tinggi, dikarenakan format paperless memmungkinkan distribusi komik elektronik memotong jalur distribusi pemasaran yang panjang, missal mulai dari percetakan sampai pengecer, sedangkan yang dimaksud dengan mobilitas yang tinggi adalah karena format komik elektronik membuat data-data yang telah berbentuk kode digital mudah dibawa ke dalam gadget dan efisien. Namun terdapat pertimbangan lain dalam hal penggunaan dan akses, dikarenakan ukuran dan format gambar yang akan didistribusikan melalui online akan mempengaruhi kecepatan akses dan bandwith internet.(d) Digital convergence, adalah perkembangan komik dalam tautan meda lain yang berbasis digital, seperti games, animasi, film, dan sebagainya, dapat digambarkan bahwa komik elektronik tidak hanya menampilkan alur cerita, namun dapat memasukan animasi, film, game, redaksi dan aplikasi lainnya sehingga memudahkan pembaca untuk memahami tiap cerita dan dapat disimpan dengan mudah secara online atau melalui gadget tertentu.

Maka komik elektronik merupakan sebuah media yang menyenangkan dapat digunakan dalam kegiatan pembelajaran di dalam kelas untuk anak usia dini, yang memiliki kelebihan berupa mobilitas tinggi dan udah dalam pendistribusian, dan dapat dipergunakan untuk menyampaikan pesan yang ingin disampaikan dengan mudah melalui cerita sehingga memunculkan penambahan pembendaharaan kosakata anak dan melatih anak agar terampil dalam berbicara. (Faisal, Baskoro, Ridwan, \& Mardawati, 2017)

Yunus mengatakan bahwa komik digital merupakan suatu bentuk cerita bergambar dengan tokoh karakter tertentu yang menyajikan informasi/pesan melalui media elektronik. Penyajian komik yang 
berbasis elektronik memungkinkan guru dapat membuat cerita komik lebih menarik dengan menambahkan unsur animasi dan suara dalam penyajiannya (Hidayah, Siswandari, \& Sudiyanto, 2018).

Berdasarkan fakta yang ada dilapangan dan penelitian yang dilakukan oleh staini menggunakan komik, dapat dilakukan untuk meningkatkan keterampilan berbicara anak (Stiani et al., 2013). Maka menggunakan komik pada penelitian ini menggunakan komik elektronik tematik yang belum pernah digunakan pada penelitian sebelumnya dengan memberikan gambar-gambar yang lebih memberi penasaran anak dan mudah untuk dipahami, Oleh karena itu peneliti melakukan penelitian untuk meningkatkan keterampilan berbicara dengan bercerita menggunakan komik elektronik tematik yang belum pernah dilakukan dalam penelitian sebelumnya sehingga dapat menjadi solusi bagi guru dalam meningkatkan keterampilan berbicara anak.

\section{METODOLOGI}

Metode penelitian yang adalah penelitian tindakan menggunakan model Kemmis dan Mc Taggart (Triyono \& Dharma, 2018) yang meliputi empat tahap yaitu perencanaan, tindakan, pengamatan, dan refleksi. penelitian ini dikatakan berhasil apabila kriteria keberhasilan mencapai $71 \%$ dari jumlah keseluruhan anak yaitu 9 dari 13 anak sudah mencapai standar yang telah ditetapkan dengan memiliki rata-rata keterampilan berbicara sebesar $71 \%$. Menerapkan dua siklus dengan 10 pertemuan. Subyek penelitian sebanyak 13 anak yang berada direntang usia 5-6 tahun, laki-laki lima anak dan perempuan delapan anak. Menggunakan teknik pengumpulan data berupa observasi, dokumentasi, wawancara, dan catatan lapangan. Instrumen dalam penelitian ini dikembangkan melalui definisi konseptual dan definisi operasional yang diambil dari aspek 1) Keterampilan berbicara anak, 2) Kemampuan bercerita, 3) Kemampuan mengungkapkan bahasa. Menggunakan analisa data kualitatif dan kuantitatif. Analisis data kualitatif Miles dan Huberman dengan cara tiga tahap analisis yaitu; reduksi data, penyajian data, dan simpulan data. Analisis kuantitatif dengan cara statistik deskriptif yang bertujuan untuk melihat rata-rata skor yang diperoleh dari pre-tindakan, siklus I, dan siklus II disajikan dalam bentuk tabel dan grafik.

\section{HASIL DAN PEMBAHASAN}

\section{Pre-intervensi}

Asesmen awal dilakukan untuk mengetahui kondisi awal ketrampilan berbicara anak di TK Setia Budhi Rangkasbitung Banten. Hasil observasi pada indikator penilaian keterampilan berbicara anak selama dua hari didapatkan hasil rata-rata pada pre-intervensi dengan persentase $33,33 \%$ data keterampilan berbicara anak, pada tabel 1. data hasil Pre-intervensi.

Tabel.1 Data Hasil Peningkatan Keterampilan Berbicara Anak dengan Bercerita Menggunakan Komik Elektronik Tematik pada pre-intervensi

\begin{tabular}{lll}
\hline \multirow{2}{*}{ No. } & Subyek & Pre-intervensi \\
\cline { 3 - 3 } & & Persentase Pencapaian \\
\hline 1 & AN & $33,33 \%$ \\
\hline 2 & AA & $33,33 \%$ \\
\hline 3 & BP & $33,33 \%$ \\
\hline 4 & FA & $33,33 \%$ \\
\hline 5 & MM & $33,33 \%$ \\
\hline 6 & MA & $33,33 \%$ \\
\hline 8 & NF & $33,33 \%$ \\
\hline 10 & NZ & $33,33 \%$ \\
\hline 11 & RF & $33,33 \%$ \\
\hline 12 & RE & $33,33 \%$ \\
\hline 13 & RA & $33,33 \%$ \\
\hline
\end{tabular}




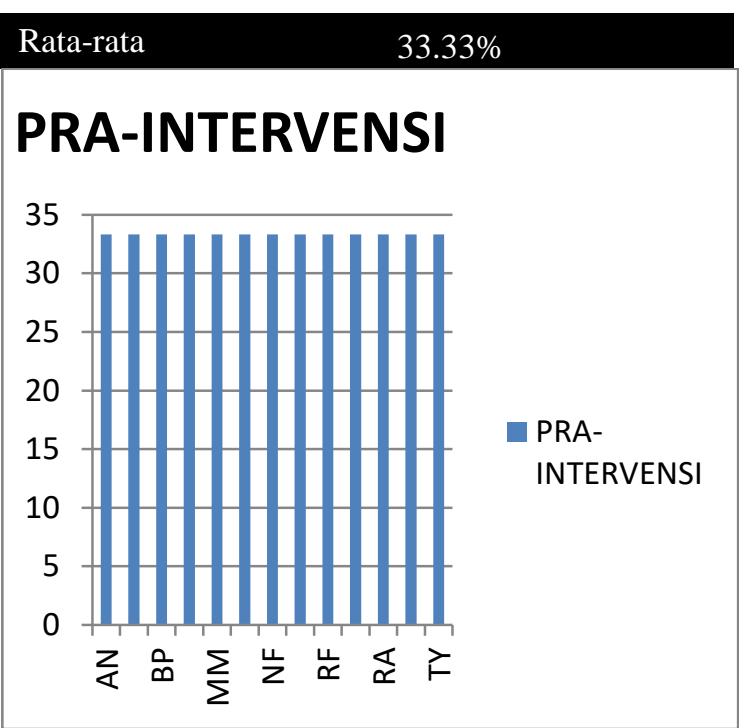

Gambar 1. Grafik Perkembangan

Keterampilan Berbicara Anak dengan Bercerita Menggunakan Komik Elektronik Tematik pada Pra Intervensi

\section{Siklus I}

Observasi pada siklus 1 dilakukan untuk mengetahui skor yang didapat oleh anak setelah diberikan tindakan melalui bercerita dengan komik elektronik tematik data keterampilan berbicara anak dapat dilihat pada tabel 2. data hasil siklus I.

Tabel 2. Data Hasil Peningkatan

Keterampilan Berbicara Anak dengan Bercerita Menggunakan Komik Elektronik Tematik pada Siklus I

\begin{tabular}{lll}
\hline \multirow{2}{*}{ No. } & Subyek & Siklus I \\
\cline { 3 - 3 } & & Persentase Pencapaian \\
\hline 1 & AN & $33,33 \%$ \\
\hline 2 & AA & $41,66 \%$ \\
\hline 3 & BP & $50 \%$ \\
\hline 4 & FA & $52.77 \%$ \\
\hline 5 & MM & $58.33 \%$ \\
\hline 6 & MA & $63.88 \%$ \\
\hline 7 & NF & $66.66 \%$ \\
\hline 8 & NZ & $69.44 \%$ \\
\hline 9 & RF & $69.44 \%$ \\
\hline 10 & RE & $69.44 \%$ \\
\hline 11 & RA & $69.44 \%$ \\
\hline 12 & SA & $69.44 \%$ \\
\hline 13 & TY & $72.22 \%$ \\
\hline Rata-rata & & $60.47 \%$ \\
\hline
\end{tabular}

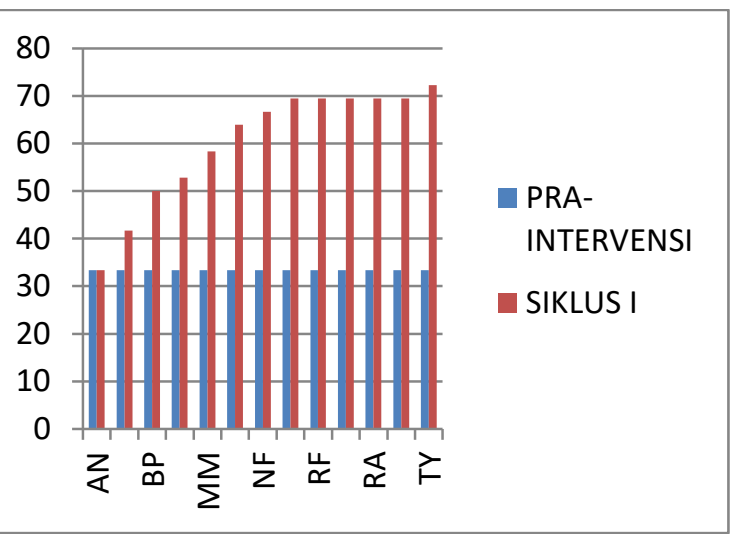

Gambar 2. Grafik Perkembangan Keterampilan Berbicara Anak dengan Bercerita Menggunakan Komik Elektronik Tematik pada Pra Intervensi Siklus I

Data pada grafik menunjukkan peningkatan keterampilan berbicara anak dari awalnya belum mendapat tindakan dengan komik elektronik. Pada grafik diatas terlihat peningkatan keterampilan berbicara anak di Tk Setia Budhi Rangkasbitung Banten yang berjumlah 13 orang anak pada rata-rata kelas preintervensi mencapai 33,33\% dan pada siklus I menjadi $60.47 \%$. Dikarenakan kriteria keberhasilan sebesar $71 \%$. Oleh karena itu peneliti dan kolaborator menyepakati untuk dilanjutkan ke siklus II. Dengan ketentuan merefleksi kekurangan pada siklus I agar lebih maksimal pada siklus II.

\section{Siklus II}

Observasi pada siklus II dilakukan untuk mengetahui skor yang diperoleh anak melalui pemberian tindakan kegiatan bermain estafet dalam meningkatkan kemampuan sosial. Untuk peningkatan keterampilan berbicara didapatkan data hasil siklus I pada Tabel. 2 
524 | Peningkatan Keterampilan Berbicara dengan Bercerita Menggunakan Komik Elektronik Tematik

Tabel 2. Tabel 2. Data Hasil Peningkatan

Keterampilan Berbicara Anak dengan Bercerita Menggunakan Komik Elektronik Tematik pada Siklus II

\begin{tabular}{lll}
\hline \multirow{2}{*}{ No. } & Subyek & Siklus II \\
\cline { 3 - 3 } & & Persentase Pencapaian \\
\hline 1 & AN & $33,33 \%$ \\
\hline 2 & AA & $83,33 \%$ \\
\hline 3 & BP & $80,55 \%$ \\
\hline 4 & FA & $75 \%$ \\
\hline 5 & MM & $83,33 \%$ \\
\hline 6 & MA & $86,11 \%$ \\
\hline 7 & NF & $77,77 \%$ \\
\hline 8 & NZ & $77,77 \%$ \\
\hline 9 & RF & $86,11 \%$ \\
\hline 10 & RE & $88,88 \%$ \\
\hline 11 & RA & $91,66 \%$ \\
\hline 12 & SA & $88,88 \%$ \\
\hline Rata-rata & & $94,44 \%$
\end{tabular}

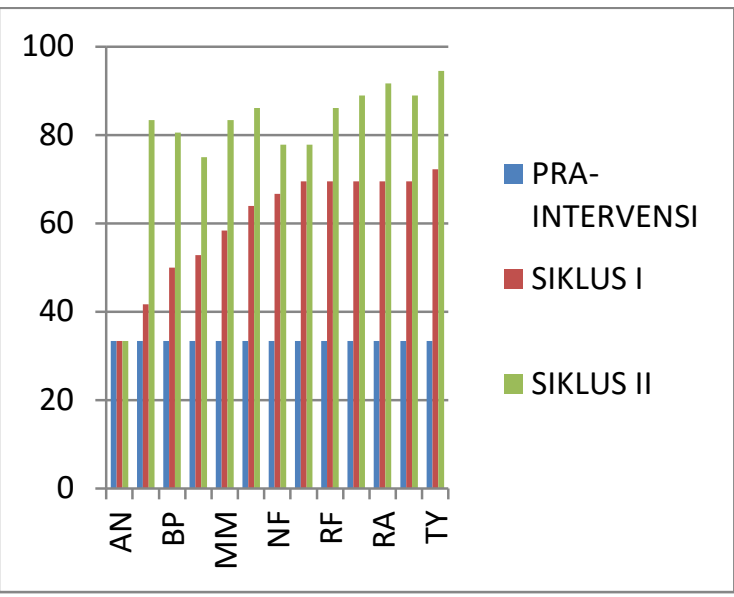

Gambar 3. Grafik Perkembangan Keterampilan Berbicara Anak dengan Bercerita Menggunakan Komik Elektronik Tematik pada Pra Intervensi Siklus II

Data pada grafik diatas menunjukkan peningkatan keterampilan berbicara di TK Setia Budhi Rangkasbitung Banten yang berjumlah 13 orang dapat dilihat pada ratarata pre-intervensi yang mencapai 33,33\% terlihat peningkatan pada siklus I yaitu $60,47 \%$, pada siklus ke II terlihat peningkatan
$80,55 \%$ yang artinya telah mencapai batas ketentuan minimal dari hasil pencapaian yang diinginkan, oleh karena itu peneliti dan kolaborator menyepakati bahwa tindakan yang dilakukan cukup sampai pada siklus II.

\section{Pembahasan}

Berdasarkan analisis data kuantitatif, penelitian ini memperoleh peningkatan keterampilan berbicara anak kelompok B,di TK Setia Budhi dari pra intervensi dengan rata-rata keterampilan berbicara sebesar $33,3 \%$ mengalami peningkatan pada siklus I menjadi $60,4 \%$ dan pada siklus II mengalami peningkatan menjadi $80,5 \%$.

Seperti yang telah disepakati bersama antar peneliti dan kolaborator jika anak telah mengalami peningkatan keterampilan berbicara rata-rata $71 \%$ dari pra-intervensi maka penelitian dikatakan berhasil dan hipotesis tindakan diterima, akan tetapi untuk menguji keajekan kemampuan anak maka peneliti tetap melanjutkan penelitian ini dengan tindakan siklus II. Hasil dari pemberian tindakan pada siklus II menunjukan keterampilan berbicara mengalami peningkatan yang sangat signifikan, seperti terlihat pada data di atas.

Data pada siklus I dan II menunjukan bahwa keterampilan berbicara anak usia 5-6 tahun di TK setia budhi pada kemampuan berbahasa dan non kebahasaan pada siklus I sudah mencapai $60.4 \%$ dan pada siklus II mencapai peningkatan $80,5 \%$ dari pra-intervensi. Data ini membuktikan bahwa peningkatan persentase keterampilan melebihi standar yang telah disepakati bersama antara peneliti dan kolaborator yaitu sebesar $71 \%$. Berdasarkan hasil tersebut menunjukan bahwa penelitian ini berhasil dan hipotesis yang menyatakan bahwa 
komik elektronik mampu meningkatkan keterampilan berbicara pada kelompok B.

Masih berdasarkan hasil observasi terhadap proses pembelajaran, juga menunjukan perubahan kearah perbaikan, kolaborator telah melaksanakan pembelajaran sesuai dengan desain pembelajaran yang telah disusun sebelumnya. Kolaborator semakin baik melaksanakan proses pembelajaran dari semua asfek yang diamati yaitu:

Pra pembelajaran yang terdiri dari a) menyiapkan ruangan/setting kelas untuk pembelajaran, b) menyiapkan media dan alat pembelajaran, c) memeriksa kesiapan anak, d) manajemen kelas

Membuka Pembelajaran yang terdiri dari: a) melakukan kegiatan awal, b) menyampaikan tujuan pembelajaran, c) memberikan penjelasan dan arahan tentang kegiatan pembelajaran melalui penggunaan media manipulatif,

Kegiatan Inti terdiri dari: a) menguasai materi yang akan disampaikan pada anak dengan komik elektronik tematik, b) mengaitkan materi dengan pengetahuan yang relevan, c) melaksanakan kegiatan bercerita dengan komik elektronik tematik. Sesuai dengan tujuan yang telah ditetapkan, d) melaksanakan kegiatan bercerita menggunakan komik elektronik tematik untuk meningkatkan keterampilan berbicara, e) memberikan keleluasaan pada anak untuk berbicara dengan komik elektronik f) memberikan semangat dan motivasi terhadap anak untuk meningkatkan keterampilan berbicara pada anak menggunakan komik elektronik tematik g) mengelola alokasi waktu dalam pembelajaran sesuai dengan rencana awal.

Hasil wawancara dengan guru juga menunjukan hasil yang sangat baik, guru berpendapat dan merasakan bahwa dengan penggunaan komik elektronik tematik dalam keterampilan berbicara anak, anak menjadi aktif dan kreatif serta bersemangat dalam mengikuti kegiatan pembelajaran. Selain itu juga guru mengatakan dengan digunakannnya komik elektronik tematik.

Hasil penelitian ini menunjukan bahwa bercerita menggunakan komik elektronik tematik dapat meningkatkan keterampilan berbicara anak. Penelitian ini menemukan pula bagaimana tingkat kebermaknaan pembelajaran dalam diri anak yang mengakar dengankuat. Kebermaknaan tersebut ditunjukan oleh anak pada saat anak menceritakan kembali kegiatan pembelajaran yang sudah mereka lakukan dihari sebelumnya. Anak mampu memberikan/menceritakan kembali dengan tingkat akurasi jawaban yang sangat baik.

\section{KESIMPULAN}

Berdasarkan hasil penelitian yang telah dilakukan diperoleh kesimpulan bahwa dengan bercerita menggunakan komik elektronik tematik dapat meningkatkan keterampilan berbicara anak secara signifikan yang dapat dilihat mulai dari preintervensi, siklus I dan siklus II. Keterampilan berbicara anak mengalami peningkatan pada pre-intervensi $33.33 \%$ meningkat menjadi $60.47 \%$ dan meningkat lagi pada siklus II mencapai $80.55 \%$ hingga dapat dinyatakan bahwa penggunaan komik elektronik tematik dapat memberikan solusi untuk meningkatkan keterampilan berbicara anak usia 5-6 tahun di TK Setia Budhi Rangkasbitung dengan didukung perlengkapan informasi dan telematika memadai, dimodifikasi sesuai dengan kebutuhan dan tema

\section{UCAPAN TERIMA KASIH}

Penulis ucapkan terimakasih kepada Dr. Nurbiana Dhieni, M.Pd selaku Koprodi S2 PAUD UNJ, Prof Dr. Yufiarti, M.Psi Selaku Pembimbing I dan Dr. Karnadi. M.Si Selaku Pembimbing II yang 
526 | Peningkatan Keterampilan Berbicara dengan Bercerita Menggunakan Komik Elektronik Tematik

telah memberikan arahan dan masukan agar penelitian yang dilaksanakan dapat selesai dengan baik. Tidak lupa orangtua, suami dan anak tercinta Rasyid Naufal Juniardi, terimakasih atas doa dan semangatnya agar penelitian ini dapat terselesaikan.

\section{DAFTAR PUSTAKA}

Aprinawati, I. (2017). Penggunaan Media Gambar Seri untuk Meningkatkan Kemampuan Berbicara Anak Usia Dini. Jurnal Obsesi: Journal of Early Childhood Education, 1(1), 72. https://doi.org/10.31004/obsesi.v1i1.68

Dewi, A. C., Hapidin, H., \& Akbar, Z. (2019). Pengaruh Model Pembelajaran dan Kemampuan Berpikir Kritis terhadap Pemahaman Sains Fisik. Jurnal Obsesi: Jurnal Pendidikan Anak Usia Dini, 3(1),

18. https://doi.org/10.31004/obsesi.v3i1.136

Faisal, Baskoro, G. W., Ridwan, M., \& Mardawati. (2017). Peningkatan kualitas pendidikan anak dengan pembangunan komik elektronik. Ikraith-Informatika, 1(2), 24-29.

Handoko. (2018). Gangguan berbicara. 5(2), $1-10$.

https://doi.org/10.13140/RG.2.2.30820.1 7285

Hidayah, Y. F., Siswandari, S., \& Sudiyanto, S. (2018). Pengembangan Media Komik Digital Akuntansi Pada Materi Menyusun Laporan Rekonsiliasi Bank Untuk Siswa Smk. Jurnal Pendidikan Dan Kebudayaan, 2(2), 239. https://doi.org/10.24832/jpnk.v2i2.588

Mabruri, Z. K., \& Aristya, F. (2017). Peningkatan Keterampilan Berbicara Pembelajaran Bahasa Indonesia Kelas IV Melalui Penerapan Strategi Role Playing SD Negeri Ploso 1 Pacitan. Jurnal Kajian Penelitan Pendidikan Dan Pembelajaran, 1(2), 112-117.

Metode, P., Erbantuan, S. B., Prabawardani, K., Agung, A., Agung, G., Parmiti, D. P., \& Pendidikan, T. (2018). SISWA KELAS V. 9, 152-163.

Pendidikan, M., Kebudayaan, D. A. N., \& Indonesia, R. (2014). No Title.

Pratiwi, R. R. (2016). Penerapan Metode
Storytelling Untuk Meningkatkan Keterampilan Berbicara Siswa Kelas Ii Sdn S4 Bandung. Jurnal Pendidikan Guru Sekolah Dasar, 1(1), 199-207.

Rahmawati, I. Y. (2017). Media Pembelajaran Komik Sebagai Inovasi Dalam Pembelajaran Keterampilan Membaca Pada Pendidikan Anak Usia Dini ( PAUD ) Berbasis Nilai Pendidikan Karakter.

Ramliyana, R. (2016). Media Komik Sebagai Upaya Peningkatan Penguasaan Kosakata Dalam Pembelajaran Bahasa Indonesia Bagi Penutur Asing ( BIPA ). 2(November), 207-218.

Shiel, G., Cregan, Á., Mcgough, A., \& Archer, P. (2012). Oral Language in Early Childhood and Primary Education (3-8 years). Educational Research Centre, 14(14), 378. https://doi.org/10.1017/CBO9781139 519397

Stiani, Y., Kemampuan, M., Anak, B., Athfal, R., Metode, M., Dengan, B., \& Media, M. (2013). Meningkatkan Keterampilan Berbicara Anak Raudatul Athfal melalui Metode Bercerita dengan Menggunakan Media Komik.

Syarah, E. S., Yetti, E., \& Fridani, L. (2018). Pengembangan Media Komik Elektronik Untuk Meningkatkan Pemahaman Konservasi Anak Usia Dini. JPUD - Jurnal Pendidikan Usia Dini, 12(2), 231-240. https://doi.org/10.21009/jpud.122.04

Tambunan, P. (2016). Pembelaj aran keterampilan berbicara di sekolah dasar. Saintech, 08(04), 79-87.

Triyono, T., \& Dharma, U. W. (2018). Penelitian Tindakan Kelas : Apa Dan Bagaimana Melaksanakannya? (March).

https://doi.org/10.13140/RG.2.2.2638 5.12649

Zuhriyah, M. (2017). Storytelling to Improve Students' Speaking Skill. English Education: Jurnal Tadris Bahasa Inggris, 10(1), 119-134. 